\title{
Figures, Maps, and Tables
}

FIGURES

I.I The fall (and rise) of Eurasia (I-20I5 AD) 3

$\begin{array}{ll}\text { 5.I China’s rising share among major Eurasian economies } & \text { IO2 }\end{array}$

5.2 From exports to a domestic driver-changing demand $\begin{array}{ll}\text { structure in the Chinese economy (2000-2017) } & \text { I03 }\end{array}$

$\begin{array}{ll}5 \cdot 3 \text { China's steel overcapacity } & \text { I09 }\end{array}$

5.4 The reorientation of Eurasian trade: from the US toward China I 8

7.I China’s rising economic scale relative to Russia (I992-2017) I49

8. I Rising EU reliance on the Chinese market (I990-20I7) I68

8.2 Rising Chinese investment in Europe $\quad$ I69

MAPS

$\begin{array}{ll}\text { I.I Land vs. sea routes } & 6\end{array}$

I.2 "Continental Drift" brings Europe and Asia closer in the post-Cold War world $\quad$ I4

2.I The classic Silk Road 27

2.2 China's Belt and Road Initiative 45

4. I China dominates continental overland routes to the West 73 
4.2 Sino-Russian maritime access dilemmas 75

4.3 India's tortured overland options $\quad 76$

4.4 Contrasting energy supply options for Europe and East Asia 79

4.5 Deepening East-West railway routes across Eurasia 90

6.I The prospective Kunming-Singapore railway network I3 I

$\begin{array}{ll}\text { 7.I China's multiple pipeline options } & \text { I44 }\end{array}$

7.2 The new Eurasian Arctic shipping frontier $\quad$ I46

8. I Expansion of the European Union (I957-2013) I66

8.2 Germany, the Visegrad Four, and the shadow of Cold War divisions $\quad$ I74

8.3 The Orient/East-Mediterranean corridor $\quad$ I76

8.4 The I6+ I Cooperation Framework Nations I80

TABLES

I.I Eurasia's formidable scale in global context 7

I.2 Top ten most populous countries (2017) 8

I.3 The looming challenge of rising energy consumption in developing Eurasia $\quad 8$

$\begin{array}{lr}\text { I.4 Systems of international order } & \text { I } 8\end{array}$

3.I Expanding Central Asian trade with Russia, China, and Turkey 58

4. I Oil reserves, production, and exports (20I7) 80

4.2 Natural gas reserves, production, and exports (2017) 80

6.I The varied patterns of overseas Chinese presence in
Southeast Asia (20I I)

9. I WMD prominence across Eurasia $\quad$ I96 